\title{
Malacological characteristic of the Weichselian Upper Pleniglacial (MIS-2) loess profile in Tłumaczów (SW Poland)
}

\author{
Witold Paweł ALEXANDROWICZ ${ }^{1, *}$, Dariusz CISZEK ${ }^{2}$ \\ and Magdalena GOŁAS-SIARZEWSKA ${ }^{1}$ \\ 1 AGH University of Science and Technology, Faculty of Geology, Geophysics and Environment Protection, Chair of Envi- \\ ronmental Analysis, Cartography and Economic Geology, Al. Mickiewicza 30, 30-059 Kraków, Poland \\ 2 Polish Geological Institute - National Research Institute, Lower Silesian Branch, Al. Jaworowa 19, 53-122 Wrocław, Poland
}

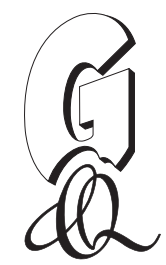

Alexandrowicz W.P., Ciszek D. and Gołas-Siarzewska M. (2013) Malacological characteristic of the Weichselian Upper Pleniglacial (MIS-2) loess profile in Tłumaczów (SW Poland). Geological Quarterly, 57 (3): 433-442, doi: 10.7306/gq.1104

The profile of silty sediments in Tłumaczów was the subject of detailed lithological and malacological analyses. Abundant malacofauna represented by typical loess species were found in the sediments. The variability of the species composition and ecological structure of faunal assemblages provided the basis for the reconstruction of the sedimentary environment and characteristics of the climatic conditions that prevailed during the deposition of the sediments. The results of analyses indicate that the described sediments belong to the youngest loess series related to the Weichselian Upper Pleniglacial (MIS-2). The sequence of molluscan assemblages shows considerable similarities to the described faunas found in numerous loess profiles in southern Poland. It differs substantially from the malacological sequences recognized in loess profiles in Western and Southern Europe. This proves the significant and climate-determined diversification of malacocoenoses during the Weichselian Upper Pleniglacial (MIS-2) in Europe.

Key words: loess, malacofauna, Weichselian Upper Pleniglacial (MIS-2), Sudetes, southern Poland.

\section{INTRODUCTION}

Loesses and loess-like sediments occurring in southwestern Poland form a number of isolated covers of various thickness. The studies of loesses in the Sudetes region were initiated by German geologists at the end of the 19th century and in the first half of the 20th century. In the after-war period, many locations were finally described in detail. Numerous regionally focused studies were also published concerning sedimentation processes and the stratigraphic aspects of silty sediments in southwestern Poland (e.g., Jary, 1996, 2007; Jary et al., 2002). Loess formations occurring in the Kłodzko Basin were studied by several authors, among the most prominent being Walczak (1952, 1957) and Cegła (1972). They noted a large outcrop in the village of Tłumaczów and mollusc shells present in the loess (Walczak, 1952, 1957). More exhaustive studies of these loesses were conducted in the 1990s. The lithology of the sediments was characterized and their stratigraphic position was determined at that time (Chlebowski et al., 2004), as were the initial malacological analyses (Alexandrowicz et al., 2001).

The malacofauna of loesses and other silty deposits in southwestern Poland is largely unexplored. Although refer-

\footnotetext{
* Corresponding author, e-mail: wpalex@geol.agh.edu.pl
}

ences to the presence of mollusc shells can be found in several studies (e.g., Walczak, 1952, 1957; Jary, 2007). This fact is of considerable importance not only in considerations regarding the local environmental conditions in which the sedimentation of aeolian dust occurred, but also in the context of regional reconstructions. A great number of locations with loess malacofauna in central and southeastern Poland (e.g., Alexandrowicz, 1986, 1991a, 1995, 2011a, b; Alexandrowicz et al., 1989; Alexandrowicz and Urban, 2002), as well as in western Ukraine (Alexandrowicz et al., 2002; Alexandrowicz and Dmytruk, 2007) have been described. Loess malacofauna have also been thoroughly investigated in the area south of the Carpathians and the Sudetes (e.g., Ložek 1965, 1969, 1991, 2001; Sümegi, 1995, 2005; Krolopp and Sümegi, 1995; Sümegi and Krolopp, 2002) as well as in eastern and western Europe (e.g., Remy, 1968; Puisségur, 1976, 1978; Rousseau, 1987, 2001; Rousseau et al., 2001, 2002; Antoine et al., 2001; Limondin-Lozouet and Gauthier, 2003; Moine, 2008). Unlike the aforementioned regions, southwestern Poland and the eastern part of Germany have relatively scarce malacological documentation. Deeper exploration of loess malacocoenoses in those areas is very important for the discussion concerning the diversity of mollusc fauna during the Weichselian Upper Pleniglacial (MIS-2) in Europe, and consequently the diversity of conditions in which the sedimentation of the youngest loess cover occurred. Therefore, the profile in Tłumaczów constitutes a substantial element of these considerations. 


\section{GEOLOGICAL SETTING}

The outcrop in Tłumaczów represents a loess cover developed in the northwestern part of the Kłodzko Basin, within the Ścinawka Depression (Chlebowski et al., 2004). The presented loess profile is situated near the mouth of the Włodzica River, where it enters the Ścinawka River, ca. $6 \mathrm{~km}$ south of Nowa Ruda, in Tłumaczów (Fig. 1). The outcrop is located at ca. $390 \mathrm{~m}$ above sea level in a flattened area on the southeastern slope of a low hill (Fig. 1). The GPS coordinates of the site are: $50^{\circ} 33^{\prime} 12^{\prime \prime} \mathrm{N}$ and $16^{\circ} 26^{\prime} 52^{\prime \prime} \mathrm{E}$. The substrate of the silty sediments are red sandstones classified as Lower Permian.

The loesses in Tłumaczów form a $10 \mathrm{~m}$ wide and $5.5 \mathrm{~m}$ high vertical wall (Fig. 2). It is possible to isolate three distinctly separate strata. From the bottom, the following layers can be distinguished:

- 5.50-3.00 m - reddish and light brick red loesses. Discontinued, yellowish and rust-coloured laminas, up to $3 \mathrm{~cm}$-thick, occur in the southern part of the outcrop. A layer containing small clasts (up to $1 \mathrm{~cm}$ across) of lower Permian sandstones lies at the lowest section of the silty sediments. The entire layer is rich in mollusc shells. The upper boundary is irregular and at some places hardly visible.

- 3.00-0.60 m - yellowish loesses with numerous vertical crevices. Irregular and often lenticular streaks, brown-red in colour, can be found. They are enriched with sandy material. Numerous small clasts of sandstones. Coarser sandstone clasts ranging up to several centimetres in size occur sporadically. Mollusc shells are present in the loesses.

- 0.60-0.00 m - a dark brown silty sediment with few sandstone clasts almost entirely affected by soil processes. This level does not contain mollusc shells.

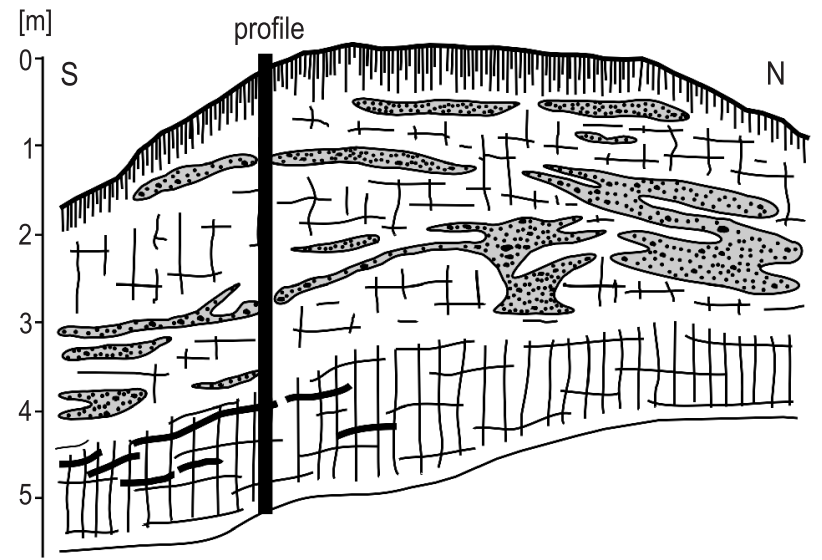

Tार recent soil

$$
\begin{aligned}
& \mp \text { yellowish loess } \quad \therefore \begin{array}{l}
\text { reddish-brown loess } \\
\text { with sand }
\end{array} \\
& \leftarrow \text { reddish loess } \quad \text { yellowish lamines }
\end{aligned}
$$

Fig. 2. Outcrop of loesses in Tłumaczów

\section{MATERIAL AND METHODS}

\section{LITHOLOGICAL ANALYSIS}

The analysis of granularity was based on the material obtained from 17 samples representing the entire profile (Fig. 3). The Casagrande's areometric method was used to determine the granular composition. The proportion of each fraction was

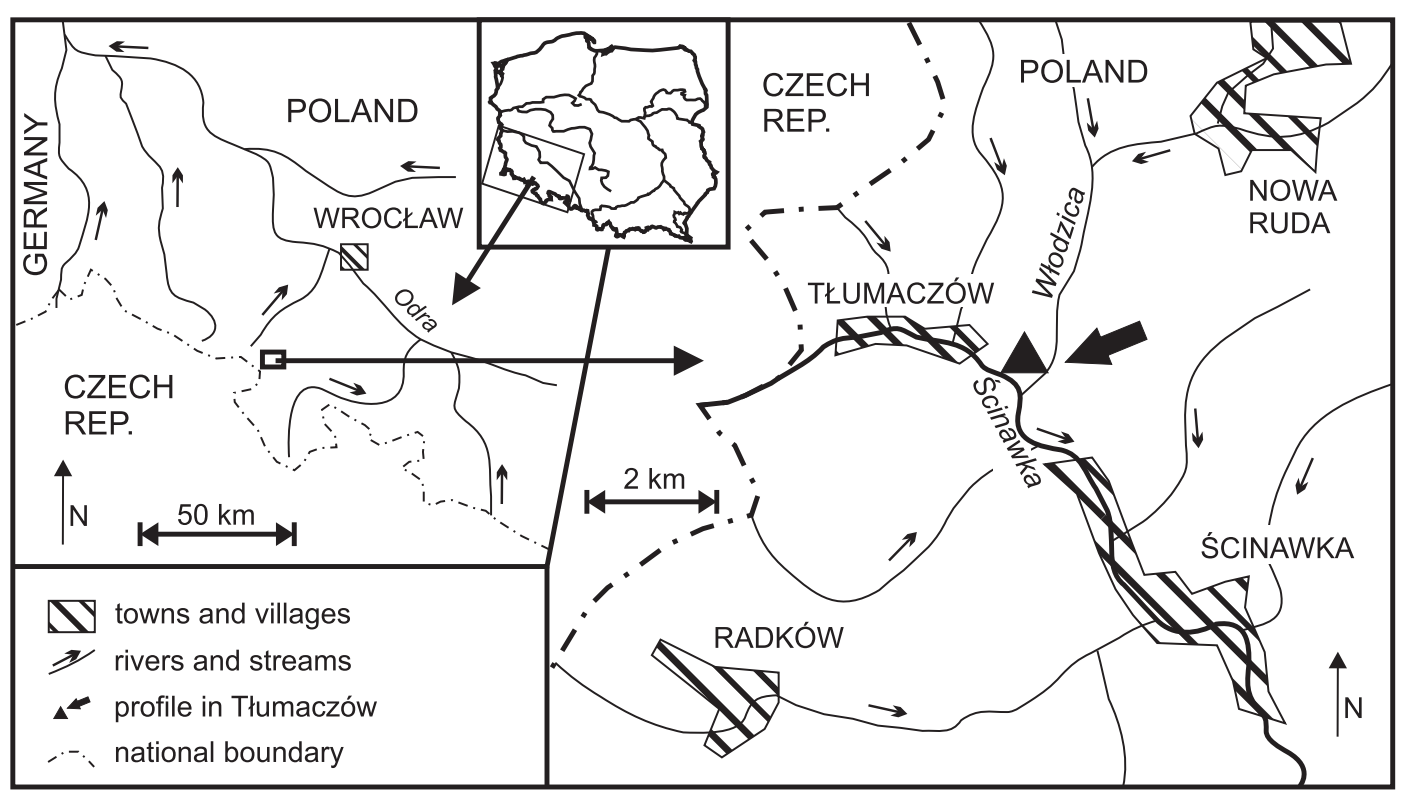

Fig. 1. Location of the loess profile in Tłumaczów 


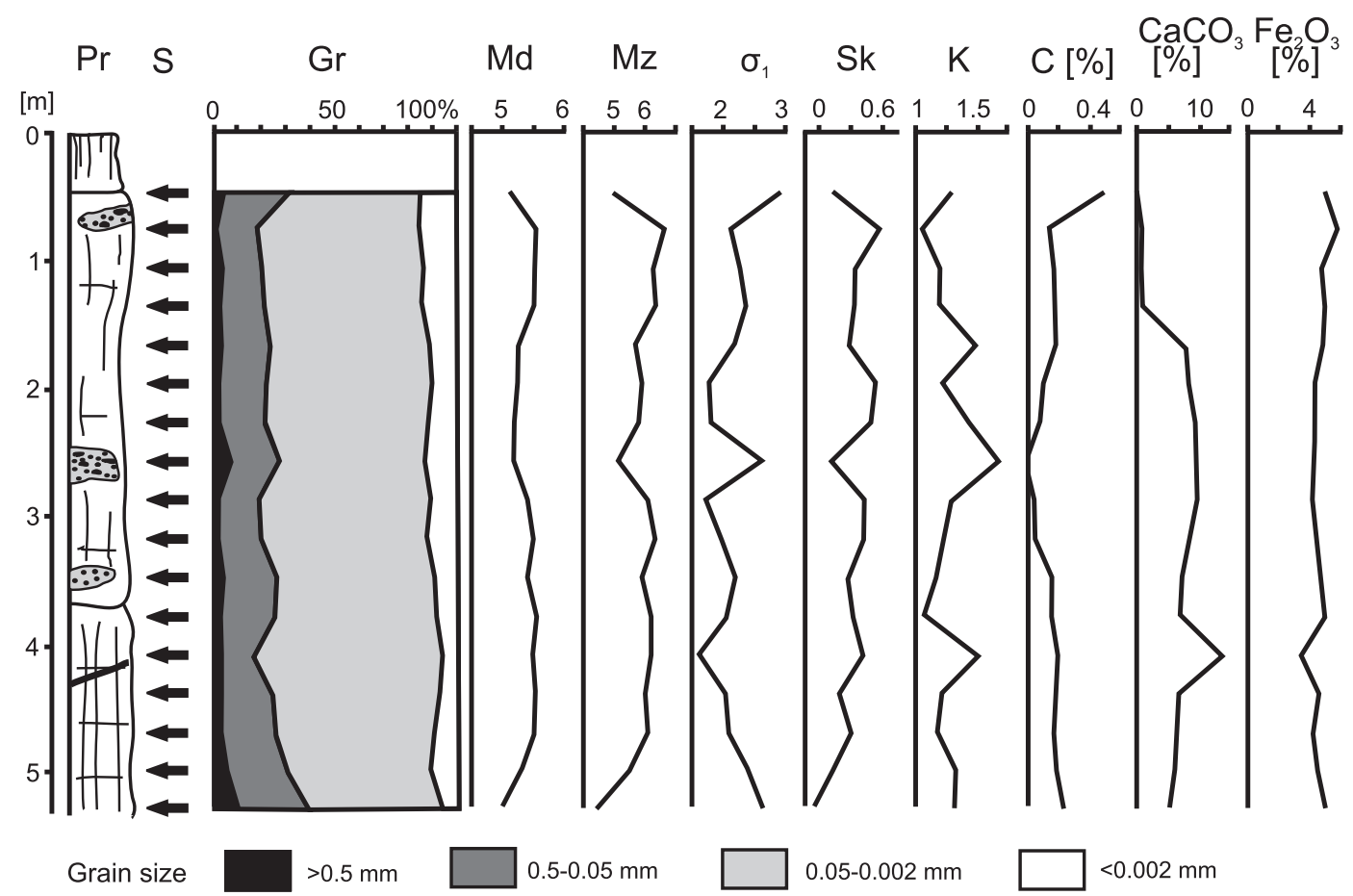

Fig. 3. Lithological and geochemical properties in the Tłumaczów locality

$\mathrm{Pr}$ - profile (for explanation see Fig. 2), S - samples, GR - grain size (phi scale), Md - median,

$\mathrm{Mz}$ - mean size, $\sigma_{1}$ - sorting, Sk - skewness, $\mathrm{K}$ - kurtosis, $\mathrm{C}$ - organic matter,

$\mathrm{CaCO}_{3}$ - calcium carbonate, $\mathrm{Fe}_{2} \mathrm{O}_{3}$ - ferrous compounds

established, and the standard granularity parameters (median - Md, mean size $-M z$, sorting $-\sigma_{1}$, skewness - Sk and kurtosis -K; Folk and Ward, 1957) were determined. The content of organic matter, carbonates and iron oxides inside the profile was also ascertained. The results of a heavy mineral analysis conducted by Chlebowski et al. (2004) were used in the interpretations as well.

\section{MALACOLOGICAL ANALYSIS}

The malacological study involved using 16 samples (Fig. 4). The locations of the sample collection correspond exactly to the locations of samples collected for the lithological analysis. The separate samples weighed ca. $2 \mathrm{~kg}$ each and represented $30-40 \mathrm{~cm}$ thick intervals. The material was subjected to flushing on a $0.5 \mathrm{~mm}$ mesh, and after drying all shells and shell fragments whose species rank could be clearly identified were selected. No molluscan remnants occurred in the sample from the roof part. The whole profile contained 8 taxa of land snails represented by more than 5000 specimens. The number of taxa varied from 4 to 7 per sample, with the number of specimens ranging from 53 to 1309 (Fig. 4).

The malacological analysis was carried out based on the methods described by Ložek (1964), Alexandrowicz (1987) and Alexandrowicz and Alexandrowicz (2011). Individual species were classified into three ecological groups:

F - shade-loving species;

$\mathrm{O}$ - species of open habitats:

$\mathrm{M}-$ mesophilous species.

Hygrophilous and aquatic species did not occur in the analysed material. The ecological requirements of particular spe- cies of snails were determined on the basis of a number of studies, and especially publications by Ložek $(1964,1965)$, Alexandrowicz (1987, 2004), Alexandrowicz and Alexandrowicz (2011). The percentage shares of species and ecological groups allowed a malacological diagram and a two-component diagram to be developed, which provided the basis for the palaeoecological interpretations. Characteristic molluscan assemblages were also identified. Based on their sequence, it was possible to reconstruct the evolution of the environment, as well as derive a number of stratigraphic conclusions. Statistical analysis was conducted using PAST software (Hammer at al., 2001), and Morisita's formula (Morisita, 1959) was used to describe the degree of overlap among the samples. On the basis of this data, a dendrogram, that illustrates clusters of samples containing faunal assemblages of similar composition and ecological structure, was developed.

\section{RESULTS}

\section{LITHOLOGICAL ANALYSIS}

The dominant fraction in the grain-size composition of the profile is definitely the silty fraction. Its proportion ranges from 47 to $63 \%$ (on average $59 \%$ ). The content of coarser fractions is equal throughout the profile, with an average ranging from $20-23 \%$. Only in the lowest section of the sequence and inside the brown-red lenses in the upper part of the profile is the proportion of the coarse fractions higher and occasionally exceeds $30 \%$. The vertical distribution of the clay fraction is not very diversified, with its content amounting to $8-15 \%$ (Fig. 3). The me- 
dian takes on similar values throughout the profile, and range between 5.0 and $5.65 \varphi$. The lowest median values apply to the bottom and roof parts of the profile and the interval at 1.7-2.5 m (Fig. 3). The mean size varies in the range 4.90-6.50 $\varphi$. The minima closely correspond to the presence of intercalations with coarser material. A considerable variation in the average diameter indicates that fairly significant changes in the energy of sedimentary environment occurred during the sedimentation of the deposits (Fig. 3). The sorting of the analysed sediments is low or very low $\left(\sigma_{1}=1.1-3.0\right)$. The least sorted parts are the formations of laminas and lenses with a greater admixture of sandy and gravel fractions (Fig. 3). Skewness is positive throughout the whole profile, which is typical of most silty formations (Fig. 3). The kurtosis values are positive throughout the profile and range between 1.0 and 1.7 (Fig. 3). The outcomes of granulometric analyses performed in the Tłumaczów location bear considerable resemblance to the results of studies conducted at other outcrops of such sediments in the Sudetes and their foothills (Jary et al., 2002; Jary, 2007).

Loesses in the Tłumaczów location are characterized by high calcium carbonate content, at some places reaching as much as $13 \%$. The lowest proportion of carbonates occurs in the roof section of the profile. The amount of organic carbon remains at a low, but fairly stable level (average $0.15 \%$ ). The relatively high content of iron oxides (mainly trivalent $-4.4 \%$ on average) gives the sediments a reddish colour (Fig. 3). The abundance of calcium carbonate is particularly important, as it creates favourable conditions for preserving molluscan shells. Similarly, high $\mathrm{CaCO}_{3}$ levels were noted in several other loess profiles in the Sudetes, where malacological material was also preserved (Jary, 2007)

\section{MALACOFAUNA}

The malacocoenosis found in the location in Tłumaczów comprises solely forms commonly noted in loess profiles (loess species sensu Ložek, 1964, 1965) and includes only 8 taxa (Table 1). Quantitative proportions of species vary distinctly between the individual sections of the sequence, which implies climatic fluctuations and the ensuing changes in the habitat features that occurred during the sedimentation of the deposits.

The molluscan fauna found in loesses exposed in Tłumaczów is characterized by a marked predominance of specimens belonging to two ecological groups: snails typical of dry and open habitats $(\mathrm{O})$ and euryecological species preferring biotopes with a slightly higher moisture (M). Shells of Arianta arbustorum - a species categorized as a form typical of shaded environments in traditional ecological classifications (Ložek, 1964; Alexandrowicz, 1987; Alexandrowicz and Alexandrowicz, 2011) - appear in the middle interval of the discussed sequence. The differences in proportions of the two mentioned groups noted in the vertical profile indicate the environmental changes which took place during the accumulation of the loess. The dominant component of the bottom part of the profile (samples 1-6) are mesophilous forms. The most characteristic is a considerable proportion of Trichia hispida, accompanied by Succinea oblonga, as well as Vallonia tenuilabris, which does not occur in the higher sections. The species of open habitats are evidently rarer (Fig. 4). In the abovementioned interval malacofauna is the most diverse in terms of species composition. The middle part of the profile (samples 7-8 and 12-14) is marked by a considerably greater share of species of open environments, represented by: Pupilla loessica, $P$. muscorum

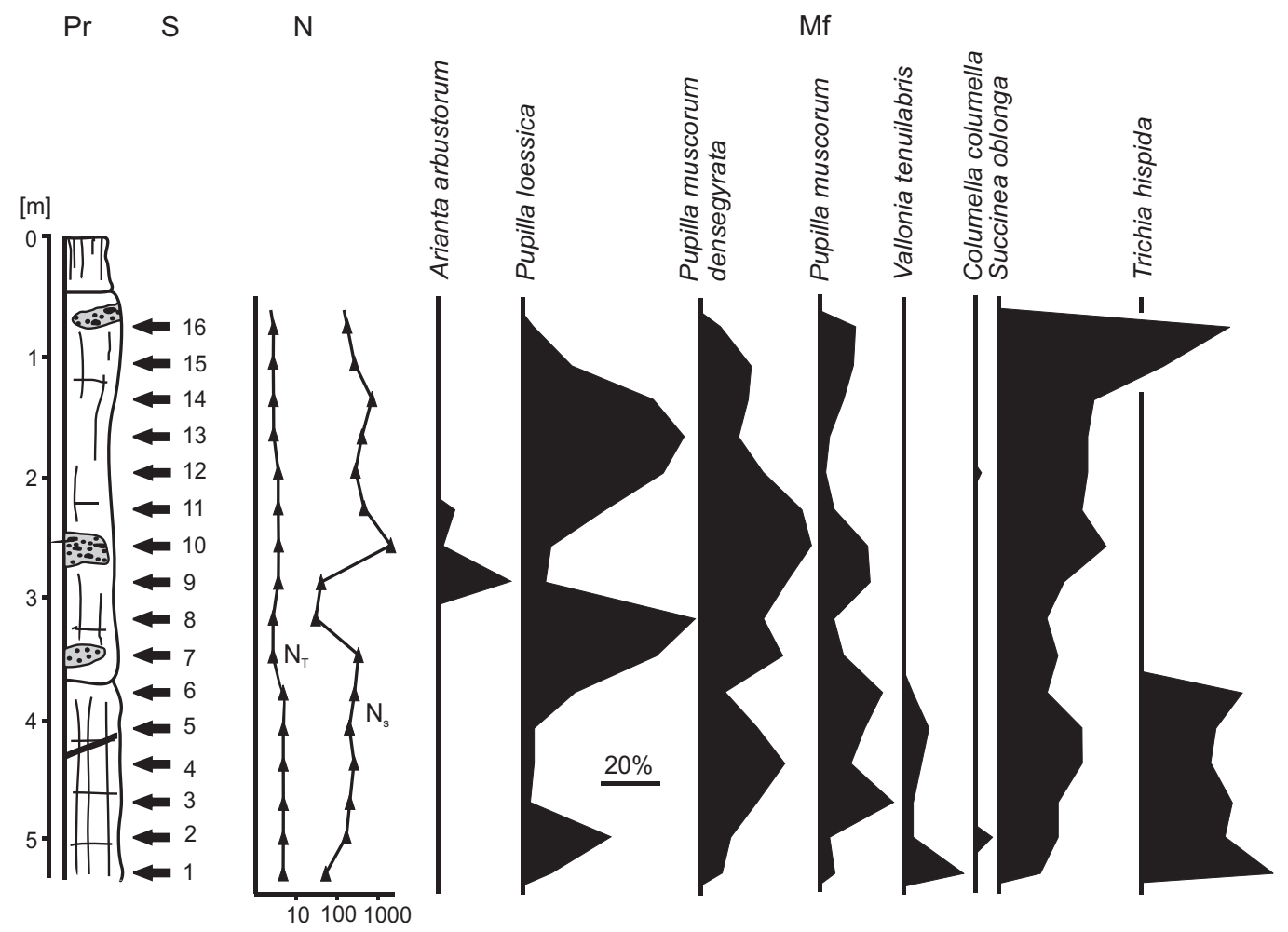

Fig. 4. Malacofauna of loess profile in Tłumaczów

$\mathrm{Pr}$ - profile (for explanation see Fig. 2), S - samples, N- number of species (NT) and specimens (NS), $\mathrm{Mf}$ - malacofauna 
Composition of malacofauna in Tłumaczów

\begin{tabular}{|c|c|c|c|c|c|c|c|c|c|c|c|c|c|c|c|c|c|}
\hline \multirow{2}{*}{$E$} & \multirow{2}{*}{ Taxon } & \multicolumn{16}{|c|}{ Samples - Tłumaczów } \\
\hline & & 1 & 2 & 3 & 4 & 5 & 6 & 7 & 8 & 9 & 10 & 11 & 12 & 13 & 14 & 15 & 16 \\
\hline $\mathrm{F}$ & $\begin{array}{c}\text { Arianta arbustorum } \\
\text { (Linnaeus, 1758) }\end{array}$ & & & & & & & & & 3 & 36 & 4 & & & & & \\
\hline $\mathrm{O}$ & $\begin{array}{c}\text { Pupilla loessica } \\
\text { Ložek, } 1954\end{array}$ & 9 & 48 & 8 & 10 & 8 & 48 & 136 & 31 & 6 & 136 & 142 & 156 & 196 & 236 & 46 & 8 \\
\hline $\mathrm{O}$ & $\begin{array}{c}\text { Pupilla muscorum } \\
\text { densegyrata } \\
\text { Ložek, } 1954\end{array}$ & 6 & 17 & 42 & 76 & 36 & 21 & 82 & 12 & 21 & 482 & 171 & 70 & 48 & 88 & 45 & 13 \\
\hline $\mathrm{O}$ & $\begin{array}{c}\text { Pupilla muscorum } \\
\text { (Linnaeus, 1758) }\end{array}$ & 4 & 6 & 56 & 59 & 29 & 56 & 24 & 3 & 12 & 211 & 23 & 8 & 11 & 41 & 29 & 22 \\
\hline 0 & $\begin{array}{l}\text { Vallonia tenuilabris } \\
\text { (Standberger, 1875) }\end{array}$ & 17 & 6 & 6 & 17 & 17 & 8 & & & & & & & & & & \\
\hline $\mathrm{M}$ & $\begin{array}{c}\text { Columella columella } \\
\text { (G. von Martens, } 1830\end{array}$ & & 10 & & & & & & & & & & 3 & & & & \\
\hline$M$ & $\begin{array}{l}\text { Succinea oblonga } \\
\text { Draparnaud, } 1801\end{array}$ & 12 & 29 & 45 & 41 & 49 & 44 & 59 & 7 & 15 & 421 & 136 & 94 & 107 & 172 & 147 & 137 \\
\hline$M$ & $\begin{array}{c}\text { Trichia hispida } \\
\text { (Linnaeus, 1758) }\end{array}$ & 38 & 44 & 68 & 62 & 45 & 93 & & & & & & & & & & \\
\hline \multicolumn{2}{|c|}{ Total species } & 6 & 7 & 6 & 6 & 6 & 6 & 4 & 4 & 5 & 5 & 5 & 5 & 4 & 4 & 4 & 4 \\
\hline \multicolumn{2}{|c|}{ Total specimens } & 86 & 166 & 225 & 265 & 184 & 270 & 301 & 53 & 78 & 1286 & 476 & 331 & 362 & 537 & 267 & 180 \\
\hline
\end{tabular}

E - ecological groups of molluscs (after Ložek, 1964; Alexandrowicz, 1987; Alexandrowicz and Alexandrowicz, 2011); F - shade-loving snails; O - open-country snails; $\mathrm{M}$ - mesophilous snails

densegyrata and $P$. muscorum. The assemblage is supplemented by Succinea oblonga. A major characteristic of the middle interval of the profile is the abundant occurrence of Arianta arbustorum shells (samples 9-11). The increase in the proportion of mesophilous taxa reveals itself in the roof fragment of the outcrop, where Succinea oblonga clearly predominates (samples 15 and 16). At the same time a rapid disappearance of Pupilla loessica becomes apparent (Fig. 4).

\section{MOLLUSCAN ASSEMBLAGES}

The taxonomic analysis enabled us to separate faunistic assemblages of different species composition, and especially with different ratios between individual taxa. Based on the dendrogram analysis (Fig. 5), four main types of fauna could be defined.

Fauna with Trichia hispida: this association was identified in samples 1-6. It demonstrates the widest diversity in species composition and relatively large numbers of specimens. Apart from the nominal taxon, the major components of this assemblage are: highly abundant Succinea oblonga, as well as the species found mostly in the roof part of the discussed section; namely: Pupilla loessica, $P$. muscorum densegyrata and $P$. muscorum. Vallonia tenuilabris is less abundant, and occurs only in this section of the sequence. The malacofauna with a species composition and ecological structure presented above indicates a cool, but not Arctic climate and a moderately humid substrate. It therefore probably corresponds to a slightly warmer and more humid period preceding the main phase of the aeolian dust accumulation. Assemblages with a similar composition and structure were noted in numerous profiles of Weichselian loess distributed across the whole of Europe (e.g., Ložek, 1965, 2001; Rousseau, 1987, 2001; Alexandrowicz,
1995, 2011a; Sümegi, 1995, 2005; Krolopp and Sümegi, 1995; Rousseau et al., 2001, 2002; Alexandrowicz et al., 2002; Alexandrowicz and Dmytruk, 2007; Moine, 2008).

Fauna with Pupilla: this is a relatively sparse malacofauna is marked by the predomination of the Pupilla genus taxa: Pupilla loessica, P. muscorum densegyrata and P. muscorum.

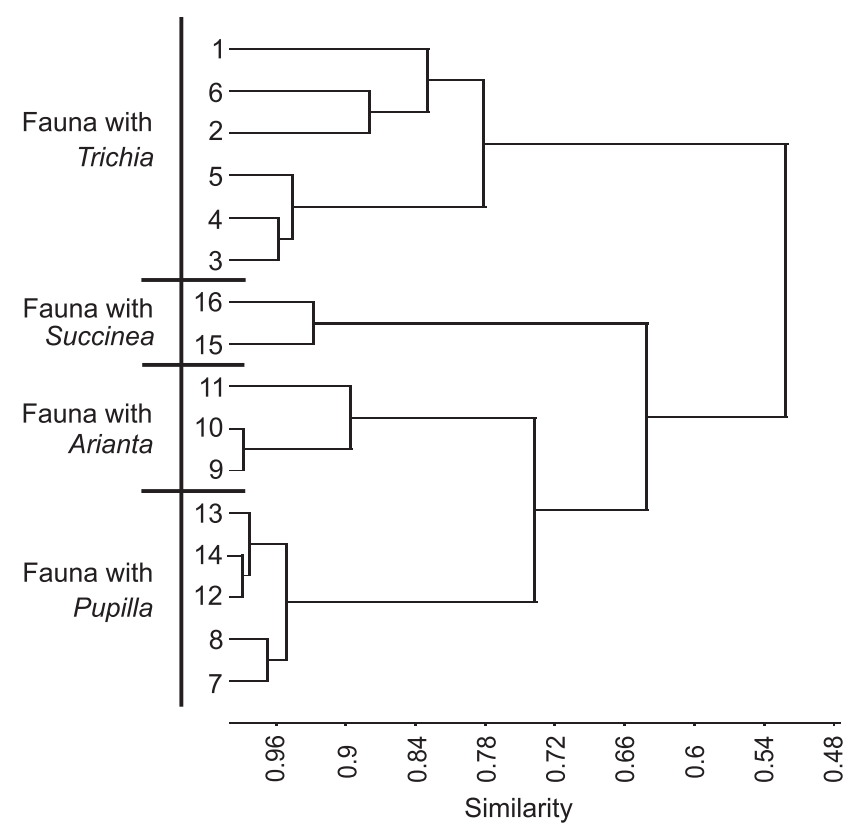

Fig. 5. Molluscan assemblages of loess profile in Tłumaczów 
A companion species is Succinea oblonga. A particularly characteristic feature is the great abundance of Pupilla loessica - a species typical of the periods of increased aeolian dust accumulation (e.g., Alexandrowicz, 1991b, 1995, 2011a, b; Alexandrowicz et al., 2002). The fauna described was found in samples 7-8 and 12-14. It as an association characteristic of periods associated with a cold and polar climate. It also indicates drying of the habitats and intensified accumulation of loess dust. The discussed fauna is considered one of the most typical assemblages occurring in loesses. It was described in numerous locations throughout Europe (e.g., Ložek, 1965, Puisségur, 1976, 1978; Rousseau, 1987, 2001; Alexandrowicz et al., 1989, 2002; Alexandrowicz, 1995, 2011a, b; Sümegi, 1995, 2005; Krolopp and Sümegi, 1995; Rousseau et al., 2001, 2002; Antoine et al., 2001; Sümegi and Krolopp, 2002; Alexandrowicz and Dmytruk, 2007; Moine, 2008) and is usually connected with the Upper Pleniglacial of the Weichselian Glaciation (MIS-2).

Fauna with Arianta arbustorum: it is a reach assemblage with large numbers of specimens. Its characteristic features are: firstly, the presence of the nominal taxon, which is accompanied by numerous individuals of Succinea oblonga, and secondly, a rapid reduction in the significance of Pupilla loessica. Such a transformation of the assemblage structure denotes a substantial change in environmental conditions, and principally an increase in habitat humidity. The assemblage in question occurs in samples 9-11. Malacocoenoses with similar composition were described in several loess locations in southern Poland and western Ukraine (Alexandrowicz, 1995; Alexandrowicz et al., 2002) and were usually associated with phases of intensified slope processes. The profile in Tłumaczów exemplifies such a similar situation.

Fauna with Succinea oblonga: this association occurs in the highest part of the profile - samples 15 and 16. It is characterized by a highly pronounced predomination of the nominal taxon and sparse occurrence of the genus Pupilla. The assemblage is typical of cold climates and indicates a progressive increase in the humidity of habitats. At the same time, it is evidence of a gradual reduction in the intensity of loess dust accumulation. The fauna outlined above was identified in locations of loess formations in Europe (e.g., Ložek, 1965, 2001; Rousseau, 1987, 2001; Alexandrowicz et al., 1989, 2002; Alexandrowicz, 1991b, 1995, 2011a, b; Sümegi, 1995, 2005; Krolopp and Sümegi, 1995; Rousseau et al., 2001, 2002; Sümegi and Krolopp, 2002; Alexandrowicz and Dmytruk, 2007; Moine, 2008)

\section{DISCUSSION}

The granulometric composition of the sediments in Tłumaczów suggests their aeolian origin. This conclusion is supported by the high calcium carbonate level observed throughout the whole profile, together with the lack of carbonates in the local rock saprolites. Therefore, the profile must be composed of an allochthonous $\mathrm{CaCO}_{3}$-rich material that originates from outside the range of Permian rocks, which constitute the substrate of the profile. On the other hand, the reddish colour of the sediments and the locally occurring clasts of Permian sandstones indicate that a slope material representing local saprolites was periodically incorporated into the loess formation process.
The loess profile in Tłumaczów depicted above contains relatively sparse molluscan fauna. However, the clear diversification in the composition and structure of assemblages that has been noted provides evidence for the changes in sedimentary environmental characteristics, which are mostly determined by regional climatic conditions, modified to a certain extent by local factors. Thus, the sequence of assemblages in the vertical profile permits the reconstruction of the environmental evolution on one hand, and the drawing of stratigraphic conclusions on the other.

The age of loesses in Tłumaczów locality was established on the basis both of regional researches of loess covers in southwestern Poland (Jary, 1996, 2007; Jary et al., 2002) and malacological data from numerous localities in southern Poland (Alexandrowicz, 1995). The malacofauna occurring the described deposits contains cold-loving snails (loess species; Ložek, 1955). Although these are essential components of mollusc assemblages associated with other cold phases of the Pleistocene (glacials) but only during MIS-2 they show such a characteristic succession and only in this period they may be used as stratigraphic indicators (Alexandrowicz, 1995, 2011a, b; Alexandrowicz et al., 2002).

In the initial period a cold, but relatively moist climate predominated, and the loess dust accumulation was not very intensive (fauna with Trichia hispida; Fig. 6). The intercalation enriched in coarser material, which forms the bottom part of the profile, is a record of the periodical intensification of slope processes. The mentioned interval involves a relatively small share of heavy minerals with a platy habit. Such minerals are considered particularly typical of formations accumulated via a dominating aeolian factor. It indicates a slow pace of loess sedimentation on one hand, and an increased humidity of the climate on the other (Chlebowski et al., 2004). In the higher section, discontinuous laminas enriched in sandy material occur. They are most likely a result of gravity-induced creep of the fine-grained roof saprolite layer. The lack of continuity of these laminas and their small thickness suggest the process is only on a minor scale (Alexandrowicz et al., 2001; Chlebowski

Molluscan assemblages

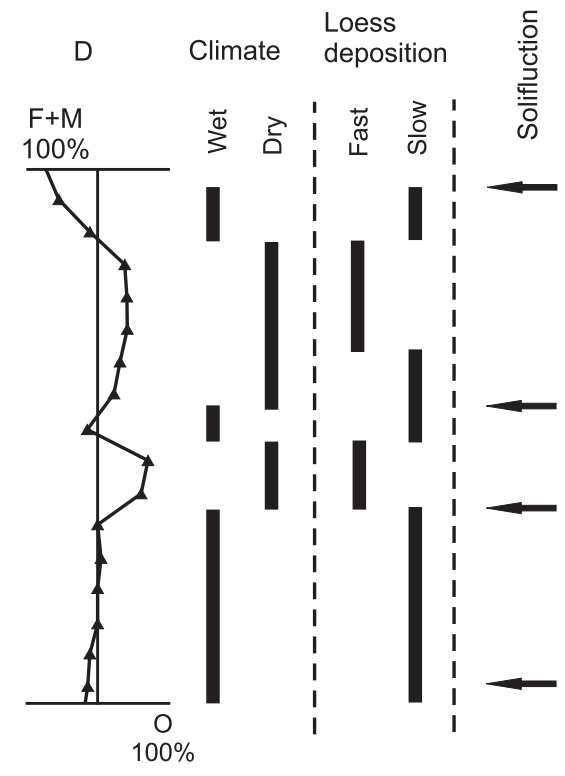

Fig. 6. Phases of development of loess series in Tłumaczów

D - two-component diagram, F - shade-loving snails,

$\mathrm{O}$ - species of open habitats, M - mesophilous forms 
et al., 2004). Towards the top, a gradual increase in the proportion of Pupilla loessica occurs. This indicates the drying of habitats, progressive cooling of the climate and a gradual rise in the pace of loess sedimentation (e.g., Ložek, 1965, 2001; Sümegi, 1995, 2005; Krolopp and Sümegi, 1995; Alexandrowicz, 1995, 2011a, b; Alexandrowicz et al., 2002; Alexandrowicz and Dmytruk, 2007).

The aforementioned fauna is particularly often noted in the loesses from the Last Glacial, exposed in the area comprising the Central Polish Uplands (Alexandrowicz, 1985, 1991b, 1995, 2011a, b; Alexandrowicz and Urban, 2002). Owing to radiocarbon analyses of samples obtained from intervals containing fauna with Trichia hispida, which were conducted in several locations, it is possible to determine the timeframe within which the assemblage occurred. It covers the period of $25-21,000$ years BP, directly prior to the phase of intensive loess sedimentation (Jersak, 1973; Maruszczak, 1980, 1996; Alexandrowicz, 1991b, 1995; Jary, 2007; Moska et al., 2011, 2012).

Above the interval described, loesses containing a sparse molluscan assemblage with numerous shells of species from the genus Pupilla (fauna with Pupilla) can be found. Such depauperation is related to the deteriorating living conditions of the molluscs, which was determined by both the progressive cooling of the climate and the intensive loess accumulation (Fig. 6). This interpretation is also confirmed by the results of heavy mineral analysis (Chlebowski et al., 2004). The strong influence of the aeolian vector phenomenon can be seen. Fauna with Pupilla typifies a severe and dry climate, bearing distinct continental features. Malacocoenoses with a similar composition and structure were found in numerous locations in Europe (e.g., Remy, 1968; Puisségur, 1976, 1978; Rousseau, 1987, 2001; Alexandrowicz et al., 1989, 2002; Alexandrowicz, 1995, 2011a, b; Sümegi, 1995, 2005; Krolopp and Sümegi, 1995; Ložek, 2001; Rousseau et al., 2001, 2002; Antoine et al., 2001; Sümegi and Krolopp, 2002; Limondin-Lozouet and Gauthier; 2003, Alexandrowicz and Dmytruk, 2007; Moine, 2008). Radiocarbon and OSL dating performed in many locations in southern Poland indicates that fauna with Pupilla is closely connected with the period $21-15,000$ years BP (Alexandrowicz, 1995; Moska et al., 2011, 2012)

The relevant interval includes intercalations of deposits containing a significant admixture of coarser fractions (gravel and sandy). The heavy mineral composition is, however, typical of aeolian formations (Chlebowski et al., 2004). A prominent change in the character of the molluscan assemblage can be seen in the section in question, which manifests itself primarily in the structural transformation of the assemblage. The fauna with Arianta arbustorum found here indicates a periodical increase in the humidity of habitats, and the presence of a considerable sandy fraction admixture in the sediments, as well as Permian sandstone clasts, resulting from the development of solifluction processes on the slopes (Fig. 6). The parallel rapid drop in the number of Pupilla loessica implies a deceleration in the loess sedimentation process. The occurrence of Arianta arbustorum shells in loess profiles was noted in many locations of such sediments in southern Poland (Alexandrowicz 1985, 1986, 1991a, b, 1995, 2001, 2011a, b; Alexandrowicz and Urban, 2002) and western Ukraine (Alexandrowicz et al., 2002; Alexandrowicz and Dmytruk, 2007). Similarly to the profile in Tłumaczów, this finding primarily concerns intervals correlated with phases of intensified slope processes.

The youngest part of the sequence contains loesses with a substantially reduced calcium carbonate level and a smaller proportion of minerals characterizing the aeolian vector (Chlebowski et al., 2004). The malacofauna found in this interval indicates a moistening of habitats and a slight, but probably pro- gressive warming of the climate (Fig. 6). The alteration of climatic conditions and the slowdown or even complete cessation of loess sedimentation caused the development of fauna with Succinea oblonga. This malacocoenosis is one of the most characteristic assemblages occurring in loess profiles. It is almost always found in their roof part, marking the end of deposition phases of the sediments. Results of studies carried out in a large number of locations in central Europe support this conclusion (Ložek, 1965, 1991, 2001; Alexandrowicz, 1985, 1991b, 1995, 2011a, b; Sümegi, 1995, 2005; Sümegi and Krolopp, 2002; Alexandrowicz et al., 2002). Radiocarbon dating from loess profiles in the Małopolska Upland (Alexandrowicz, 1995) show that the phase falls in the period from 15-14,000 years BP.

\section{DISCUSSION AND CONCLUSIONS}

The malacofauna described in the Tłumaczów profile is characteristic of loess formations. Both composition and structure of separate assemblages, as well as the sequence in which they occur in the vertical profile, show a strong resemblance to numerous locations of loesses described in southern Poland, as well as the profiles of loess-like sediments in the Carpathians (Alexandrowicz, 1988; Cieszkowski et al., 2010). Detailed malacological studies in the aforementioned areas enabled a model to be defined, of changes in malacofauna and the sequences of faunal assemblages during the accumulation of loess covers associated with the Weichselian Upper Pleniglacial (MIS-2) (e.g., Ložek, 1965, 1969, 1991, 2001; Remy, 1968; Puisségur, 1976, 1978; Alexandrowicz, 1985, 1991b, 1995, 2011a, b; Rousseau, 1987, 2001; Alexandrowicz et al., 1989, 2002; Sümegi, 1995, 2005; Krolopp and Sümegi, 1995; Rousseau et al., 2001, 2002; Antoine et al., 2001; Sümegi and Krolopp, 2002; Limondin-Lozouet and Gauthier, 2003; Alexandrowicz and Dmytruk, 2007; Moine, 2008). The aforementioned model applies both to the character of the sedimentary environment and the stratigraphical aspects. Based on the diversification of habitat types, it is possible to distinguish three loess varieties containing different assemblages of fauna. The first type includes sediments deposited in dry habitats, mostly on high plains and gently inclined slopes. The characteristic feature of the malacocoenoses found there is low species diversity and predomination of taxa typical of open and relatively dry environments; namely: Pupilla muscorum, P. muscorum densegyrata, P. loessica and Vallonia tenuilabris, almost always accompanied by Succinea oblonga, and sometimes also by Arianta arbustorum and Trichia hispida. Classified as the second type are loesses accumulating in the beds of valleys and in lower parts of slopes. The malacofauna occurring there is usually marked by greater species diversity. Apart from typical "loess species", cold-loving forms typical of habitats with highly increased humidity are also present, such as: Columella columella, Vertigo genesii, Vertigo geyeri and Vertigo parcedentata. The third type encompasses sediments formed by loessial material, but accumulating in aquatic environments. The presence of cold-loving molluscs characteristic of shallow bodies of water, such as Gyraulus laevis, Galba truncatula, Pisidium obtusale laponicum and Pisidium stewarti is a distinctive feature (e.g., Alexandrowicz, 1985, 1991b, 1995). Given the composition of the fauna described in the Tłumaczów profile, it can be classified as the first of the types presented above. Radiocarbon dating together with the results of malacological analyses performed in numerous loess profiles in southern Poland, have al- 
lowed one to discern several climatic phases (Jersak, 1973; Maruszczak, 1980, 1996; Alexandrowicz, 1995). The earliest one (cool and humid), not represented in Tłumaczów, covers the period $32-25$ ka BP. A minor warming phase is distinguishable between 25 and $21 \mathrm{ka}$ BP. This period entails the appearance of characteristic fauna with Trichia hispida found in the lower interval in the Tłumaczów sequence. The subsequent phase (21-15 ka BP) is marked by a very cold, polar and dry climate. This phase involves a very intensive accumulation of loesses and the development of the distinctive fauna with Pupilla (middle part of the profile). In Tłumaczów, as in several locations in the Kraków region within a loess series, intercalations and laminas enriched in sandy material, or even small rock clasts, can be found. It is a consequence of a periodical intensification of slope processes, which is most likely due to local, small-scale phenomena. The last phase of the loess accumulation constitutes a period of progressively rising humidity and a slight warming of the climate (15-14 ka BP). Faunal assemblages dominated by Succinea are its characteristic feature.

The above-presented sequence of faunal assemblages is typical of loesses in southern Poland, as well as western Ukraine (Alexandrowicz, 1985, 1995, 2001, 2011a, b; Alexandrowicz et al., 1989, 2002; Alexandrowicz and Urban, 2002; Alexandrowicz and Dmytruk, 2007). Compared with numerous other locations of loess faunas described in other European countries it shows fairly substantial differences. This observation contradicts Ložek's views (1965) concerning the considerable homogeneity of the loess faunas of Europe. Loesses situated in an area south of the Carpathians and the Sudetes are usually characterized by a far more diversified molluscan fauna (Ložek, 1965, 1969, 1991, 2001; Sümegi, 1995, 2005; Krolopp and Sümegi, 1995; Sümegi and Krolopp, 2002; Marković et al., 2008). Particularly significant is the abundance of the xerophilous species, which manifest at considerably higher temperatures. These forms do not occur in locations north of the
Carpathians. Further southwards, these disparities become more pronounced. In western Europe it is possible to distinguish two evidently different areas: namely the western and the central zones (Moine, 2008). The first one includes the southern part of the British Isles and northern France and is marked by the occurrence of faunistic assemblages, with a less diversified species composition. Characteristic forms include: Pupilla muscorum, Columella columella, Succinea oblonga and Tricha hispida (Gao et al., 2000; Lautridou and Cliquet, 2006; Moine, 2008). The assemblages found in the central area - in the Rhine Valley and Germany - have a much more diversified species composition (Remy, 1968; Puisségur, 1976, 1978; Rousseau, 1987, 2001; Rousseau et al., 2001, 2002; Antoine et al., 2001; Limondin-Lozouet and Gauthier, 2003; Moine, 2008). The causes of this divergence are difficult to determine explicitly and they can include climatic or topographic factors, as well as reflect specific local conditions in the case of some profiles (Moine, 2008).

In this context the distinctness of malacocoenoses found in the loesses of western Ukraine and southern Poland, including the location in Tłumaczów, can be interpreted as an effect of the cold, polar, but relatively dry climate prevailing in those areas during the Weichselian Upper Pleniglacial (MIS-2), combined with the considerably stronger influence of continental conditions. Another characteristic feature is the abundant occurrence of two Asian species in the locations in southern Poland; namely: Pupilla loessica and Vallonia tenuilabris, which migrated along with progressive cooling of the climate from central Asia to the loess areas of Europe.

Acknowledgments. The authors are greatly indebted to Prof P. Sümegi, Prof Z. Jary and an anonymous reviewer for critical valuable remarks. This study has been sponsored by the AGH University of Science and Technology through the University grant no. 11.11.140.175

\section{REFERENCES}

Alexandrowicz S.W. (1985) Molluscan assemblages of the Polish loess. In: International Symposium: Problems of the Stratigraphy and Paleogeography of Loess, Guide Book (ed. H. Maruszczak): 55-61.

Alexandrowicz S.W. (1986) Molluscan assemblages from a loess profile at Odonów (Małopolska Upland). Biuletyn Peryglacjalny, 31: 7-15.

Alexandrowicz S.W. (1987) Malacological analysis in Quaternary research (in Polish with English summary). Kwartalnik AGH, Geologia, 12 (1-2): 3-240.

Alexandrowicz S.W. (1988) Malacofauna of the Late Quaternary loess-like deposits in the Polish Carpathians. Acta Geologica Polonica, 38: 85-106.

Alexandrowicz S.W. (1991a) Malakofauna i wiek lessów z Maszkowa w Dolinie Dłubni. Geografia, 50: 379-387.

Alexandrowicz S.W. (1991b) Malakofauna utworów lessowych w Polsce. In: Podstawowe profile lessów w Polsce (ed. H. Maruszczak): 36-49. Wydawnictwo UMCS, Lublin.

Alexandrowicz S.W. (1995) Malacofauna of the Vistulian loess in the Cracow Region (S Poland). Annales UMCS, B, 50: 1-28.

Alexandrowicz S.W., Alexandrowicz W.P. (2011) Analiza malakologiczna. Metody badań i interpretacji. Rozprawy Wydziału Przyrodniczego PAU, 3: 5-302.
Alexandrowicz S.W., Butrym J., Maruszczak H. (1989) The malacofauna of the Younger and Older loess of the Przemyśl region, SE Poland. Folia Malacologica, 3: 7-21.

Alexandrowicz W.P. (2004) Molluscan assemblages of Late Glacial and Holocene calcareous tufa in Southern Poland. Folia Quaternaria, 75: 3-309.

Alexandrowicz W.P. (2011a) Fauna of molluscs from less profile at Wola Chroberska (Nida Basin, southern Poland) (in Polish with English summary). Annales UMCS, B, 56 (1): 77-91.

Alexandrowicz W.P. (2011b) Molluscan communities in Vistulian loess located in Chobrzany, a village near Sandomierz (Southern Poland) (in Polish with English summary). Kwartalnik AGH, Geologia, 37 (3): 357-373.

Alexandrowicz W.P., Boguckyj A., Dmytruk R., Łanczont M. (2002) Molluscs of loess deposits in the Halych Prydniestrov'ja region (in Polish with English summary). Studia Geologica Polonica, 119: 253-290.

Alexandrowicz W.P., Ciszek D., Łopuszyńska M. (2001) Profil i malakofauna lessów w Tłumaczowie na Dolnym Ślasku. Sprawozdania z Czynności i Posiedzeń PAU, 64: 175-177.

Alexandrowicz W.P., Dmytruk R. (2007) Molluscs in Eemian-Vistulian deposits of the Kolodiiv section, Ukraine (East Carpathian Foreland) and their palaeoecological interpretation. Geological Quarterly, 51 (2): 173-178. 
Alexandrowicz W.P., Urban J. (2002) Documentary sites of less in Kozubów Landscape Park (in Polish with English summary). Chrońmy Przyrodę Ojczystą, 58 (4): 5-36.

Antoine P., Rousseau D.D., Zöller L., Lang A., Munaut A.-V., Hatté C., Fontugne M. (2001) Highresolution record of the last Interglacial-glacial cycle in the Nussloch loess-paleosoil sequences. Quaternary International, 76-77: 211-229.

Cegła J. (1972) Loess sedimentation in Poland (in Polish with English summary). Acta Universitatis Wratislaviensis, 168: 3-72.

Chlebowski R., Ciszek D., Jary Z., Kida J. (2004) Origin of the loesses and loess-like deposits from Tłumaczów (Central Sudetes) and Branice (Głubczyce Plateau) based on mineralogical analyses. Quaestiones Geographicae, 23: 33-40.

Cieszkowski M., Zuchiewicz W., Alexandrowicz W.P., Wojtal P. (2010) A new find of mammoth tusk in loess-like sediments of the Zakliczyn Basin (Outer Western Carpathians, Poland). Annales Societatis Geologorum Poloniae, 80: 89-99.

Folk R.L., Ward W.C. (1957) Brazos River Bar: A study in the significance of grain size parameters. Journal of Sedimentary Petrology, 27: 3-27.

Gao C., Keen D.H., Boreham S., Coope G.R., Pettit E., Stuart A.J., Gibbard P.L. (2000) Last Interglacial and Devensian deposits of the River Great Ouse at Woolpack Farm, Fenstanton, Cambridgeshire, UK. Quaternary Science Reviews, 19 (8): 787-810.

Hammer Q., Harper D.A.T., Ryan P.D. (2001) Past: paleontological statistics software package for education and data analysis. Palaeontologica Electronica, 4: 1-9.

Jary Z. (1996) Chronostratigraphy and the course of loess sedimentation in SW Poland on the example of the Głupczyce Upland and Trzebnica Hills (in Polish with English summary). Acta Universitatis Wratislaviensis, 1766: 63: 3-103.

Jary Z. (2007) Record of the climate changes in Upper Pleistocene loess-soil sequences in Poland and western part of Ukraine (in Polish with English summary). Rozprawy Naukowe Instytutu Geografii i Rozwoju Regionalnego Uniwersytetu Wrocławskiego, 1: 5-136.

Jary Z., Kida J., Śnihur M. (2002) Loess and loess-derived sediments in SW Poland (in Polish with English summary). Czasopismo Geograficzne, 73 (1-2): 63-100.

Jersak J. (1973) Lithology and stratigraphy of the loess on the Southern Polish Uplands (in Polish with English summary). Acta Geographica Lodziensia, 32: 3-139.

Krolopp E., Sümegi P. (1995) Palaeoecological reconstruction of the Late Pleistocene, based on Loess Malacofauna in Hungary. GeoJournal, 36: 213-222.

Lautridou J.-P., Cliquet D. (2006) Le Pléistocene supérieur de Normandie et peuplements paléolithiques. Quaternaire, 17: 187-206.

Limondin-Lozouet N., Gauthier A. (2003) Biocénoses pléistocénes des sequences loessiques de Villiers-Adam (Val d'Oise, France): études malacologiques et palynologiques. Quaternaire, 14 (4): 237-252.

Ložek V. (1964) Quartärmollusken der Tschechoslovakei. Rozpravy Ustředniho Ustavu Geologického, 31: 3-374.

Ložek V. (1965) Das Problem der Lössbildung und die Lössmollusken. Eiszeit und Gegenwart, 16: 61-75.

Ložek V. (1969) Paläontologische Charakteristik der Lösserien. Periglacial, Löss und Paläolith Tschechoslovakei: 43-59.

Ložek V. (1991) Molluscs in loess, their paleoecological significance and role in geochronology - principles and methods. Quaternary International, 7-8: 71-79.

Ložek V. (2001) Molluscan fauna from the loess series of Bohemia and Moravia. Quaternary International, 76-77: 141-156.
Marković S.B., Bokhorst M., Vandenberghe J., Oches E.A., Zöller L., McCoy W.D., Gaudenyi T., Jovanović M., Hambach U., Machalett B. (2008) Late Pleistocene loess-paleosol sequences in the Vojevodina region, North Serbia. Journal of Quaternary Science, 23: 73-94.

Maruszczak H. (1980) Stratigraphy and chronology of the Vistulian loesses in Poland. Quaternary Studies in Poland, 2: 57-76.

Maruszczak H. (1996) Stratigraphic correlation of Polish, Ukrainian and German loesses (in Polish with English summary). Biuletyn Państwowego Instytutu Geologicznego, 373: 107-115.

Moine O. (2008) West-European malacofauna from loess deposits of the Weichselian Upper Pleniglacial: compilation and preliminary analysis of the database. Quaternaire, 19 (1): 11-29.

Morisita M. (1959) Measuring of interspecific association and similarity between communities. Memories of the Faculty of Science, Kyushu University, E-3: 65-80.

Moska P., Adamiec G., Jary Z. (2011) OSL dating and lithological characteristics of loess deposits from Biały Kościół. Geochronometria, 38 (2): 162-171.

Moska P., Adamiec G., Jary Z. (2012) High resolution dating of loess profile from Biały Kościół, south-west Poland. Quaternary Geochronology, 10: 87-93.

Puisségur J.J. (1976) Mollusques continentaux quaternaries de Bourgogne. Significations stratigraphiques et climatiques. Rapports avec d'autres faunes boréales de France. Mémoires Géologiques de I' Université de Dijon, 3.

Puisségur J.J. (1978) Les mollusques des series loessiques a Achencheim. Recherches géographiques Strasbourg, 7: 71-96.

Remy H. (1968) Zur Stratigraphie und Klimaentwicklung des jüngeren Pleistozäns in Mittel- und Westeuropa unter besonderer Berücksichtigung des Lösses. Decheniana, 121: 121-145.

Rousseau D.D. (1987) Paleoclimatology of the Achenheim Series (Middle and Upper Pleistocene, Alsace, France). A malacological analysis. Palaeogeography, Palaeoclimatology, Palaeoecology, 59: 293-314.

Rousseau D.D. (2001) Loess biostratigraphy - new advances and approaches in mollusk studies. Earth-Science Reviews, 54: $151-171$.

Rousseau D.D., Gerasimenko N., Matviischina Z., Kukla G. (2001) Late Pleistocene environments of the Central Ukraine. Quaternary Research, 56: 349-356.

Rousseau D.D., Antoine P., Hatté C., Lang A., Zöller L., Fontugne M., Ben Othman D., Luck J.-M., Moine O., Labonne M., Bentaleb I., Jolly D. (2002) Abrupt millennial climatic changes from Nussloch (Germany) Upper Weichselian aeolian records during the Last Glaciation. Quaternary Science Reviews, 21 (14-15): 1577-1582.

Sümegi P. (1995) Quartermalacological analysis of Late Pleistocene loess sediments of the Great Hungarian Plain. Malacological Newsletter Supplement, 1: 79-111.

Sümegi P. (2005) Loess and Upper Paleolithic environment in Hungary. Aurea, Nagykovasci.

Sümegi P., Krolopp E. (2002) Quartermalacological analysis for modeling of the Upper Weichselian palaeoenvironmental changes in the Carpathian Basin. Quaternary International, 91: 53-63.

Walczak W. (1952) Stratigraphy of the Pleistocene in the valley of the Ścinawka (in Polish with English summary. Biuletyn Państwowego Instytutu Geologicznego, 68 (4): 351-385.

Walczak W. (1957) Czwartorzęd i morfologia Kotliny Kłodzkiej. Przewodnik XXX Zjazdu Polskiego Towarzystwa Geologicznego: 24-34. 